\title{
Instant Immunization Against SARS-CoV-2 (COVID-19): A Novel Hypothesis
}

\section{Ganesh Kumar K Ammannaya $^{1 *}$ | Ninada Sripad ${ }^{2}$}

*Correspondence: Ganesh Kumar K Ammannaya

Address: ${ }^{1}$ American Association for Thoracic Surgery (AATS) Visiting Fellow, NYU Langone Health, NY, USA; ${ }^{2}$ Clinical Microbiologist, Goa Medical College, Goa, India

e-mail $\bowtie$ : doc.ammannaya@gmail.com

Received: 05 May 2020; Accepted: 13 May 2020

Copyright: (C) 2020 Ammannaya GKK. This is an open-access article distributed under the terms of the Creative Commons Attribution License, which permits unrestricted use, distribution, and reproduction in any medium, provided that the original work is properly cited.

\section{ABSTRACT}

We are amidst a raging coronavirus pandemic that has already infected over 2.6 million people and further accelerating. The much needed vaccine for COVID-19 is still several months away. Therefore, we present a novel hypothesis which could possibly be our quickest and the simplest solution to instant and widespread immunization.

Keywords: Immunization, SARS-CoV-2, COVID-19, Coronavirus

\section{Introduction}

The ongoing coronavirus pandemic has claimed more lives than any other pandemic since the Spanish flu. It has overwhelmed the healthcare systems across the world and pushed a few nations like Italy to almost a breaking point.

As the vaccine for COVID-19 is several months away, we need something urgently to curb this pandemic, which is now further accelerating, having affected over 850,000 Americans and over 2.6 million worldwide at the time of writing this article on April 22, 2020.

\section{Hypothesis}

In 1994, VanCott JL, et al. (1994) in their experiment on porcine model showed that, immunization against respiratory coronavirus via GALT (gut-associated lymphoid tissues) induced IgA-ASC (Absecreting cells) and provided complete respiratory protection. In the said study, IgA-ASC in the duodenum and jejunum constituted the major ASC response. Although the administration of vaccines intranasally may not be optimally effective for inducing intestinal immunity, the efficacy of oral vaccines for inducing respiratory immunity has been previously thus well demonstrated (Saif, 1996).

More recently in 2014, Liu J, et al. (2014) showed that oral vaccination with a liposomeencapsulated influenza DNA vaccine protects mice against respiratory challenge infection. Therefore, it 
has been continually proved that mucosal immunity can confer immunity against viral respiratory infections whether the flu or coronavirus in the animal models. In 2016, Kim L, et al. (2016) used radiocontrolled capsules to deliver the vaccine to either the jejunum or the ileum. The resulting immune response was investigated. Both intestinal sites were capable of inducing mucosal and systemic immune responses with ileum delivery inducing higher numbers of antibody secreting cells of IgG and IgA isotypes, increased mucosal homing B cells, and higher number of vaccine responders.

This leads to our hypothesis that, oral administration of a small amount of the live virus (SARS-CoV2), can activate the mucosal immunity in the gut through GALT, thereby possibly conferring immunity against COVID-19. This pre-measured viral load can be delivered into small bowel through a capsule, so as to protect the viral load from the gastric acid and deliver the same to the small bowel, where ASC response is maximum.

\section{Discussion}

Oral live vaccine for coronovirus has been successfully tested almost three decades back in animal models, but never in humans. The CDC (Center for Disease Control, Atlanta, USA) and other research centres across the globe can develop on this novel hypothesis outlined in this article by reaffirming the results on animal model with regard to the novel coronavirus, upon the success of which on healthy volunteers in a guarded environment and measure the antibodies developed. Ultimately, the required viral load can be titrated depending on the antibody response and safety considerations.

Needle-free vaccination could offer several distinct advantages over intramuscular injections such as being painless, easier to distribute and administer leading to rapid and widespread immunization and reduced vaccination costs. Moreover, vaccine delivery via the alimentary tract might elicit mucosal immune responses at the site of virus entry and better cellular immunity, thus improving effectiveness (Amorij et al., 2010). Arguably, the cellular immunity so conferred may be superior to the spike protein targeted vaccines that are being extensively investigated in various clinical trials. Another key advantage of an oral vaccine so developed is the flexibility of incorporating different or mutated strains into it, while the same is not feasible in the conventional flu vaccines.

In this time of unprecedented crisis, this could possibly be our quickest and the simplest solution to instant widespread immunization. I hope this article paves way for the development of an effective and novel vaccine to control COVID-19, much before the arrival of the conventional vaccines. 


\section{Acknowledgments: None}

Financial Disclosure or Funding: None

\section{Conflict of Interest: None}

\section{References}

Amorij JP, Hinrichs WLj, Frijlink HW, Wilschut JC, Huckriede A. Needle-free influenza vaccination [published correction appears in Lancet Infect Dis.2010 Nov;10(11):740]. Lancet Infect Dis 2010; 10: 699-711.

Kim L, Martinez CJ, Hodgson KA, Trager GR, Brandl JR, Sandefer EP, Doll WJ, Liebowitz D, Tucker S. Systemic and mucosal immune responses following oral adenoviral delivery of influenza vaccine to the human intestine by radio controlled capsule. Sci Rep 2016; 6: 37295.

Liu J, Wu J, Wang B, Zeng S, Qi F, Lu C, Kimura Y, Liu B. Oral vaccination with a liposome-encapsulated influenza DNA vaccine protects mice against respiratory challenge infection. J Med Virol 2014; 86: 886-894.

Saif LJ. Mucosal immunity: an overview and studies of enteric and respiratory coronavirus infections in a swine model of enteric disease. Vet Immunol Immunopathol 1996; 54: 163-169.

VanCott JL, Brim TA, Lunney JK, Saif LJ. Contribution of antibody-secreting cells induced in mucosal lymphoid tissues of pigs inoculated with respiratory or enteric strains of coronavirus to immunity against enteric coronavirus challenge. J Immunol 1994; 152: 3980-3990. 